\title{
Obituary: Dr. BBS Rana
}

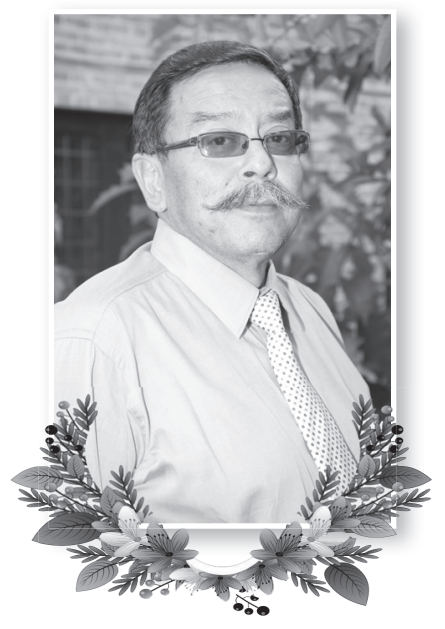

Dr. Bir Bahan Shamser Rana was a Senior Consultant Physician at the Kathmandu Medical College Teaching Hospital and chief of Unit Two of the Departmentof Medicine from $1^{\text {st }}$ December 2014 until his death on $29^{\text {th }}$ January 2018. He was a Founder Member of Board of Directors of Kathmandu Medical College. As a head of the Emergency Department from 19 ${ }^{\text {th }}$ September 2008 until his death, he contributed towards the development of emergency service. The first 64 slice CT scanner was introduced at Kathmandu Medical College Teaching Hospital in the year 2008. This CT scanner service was run by a management committee and Dr. Rana was the Chairman of this committee from 2008 to 2016.

Physically, Dr. Rana was a big man, but it was his knowledge of medicine and interest in bedside teaching of medical students that made him popular among the medical students. He graduated from Rachi Medical College in 1983. He then studied at AlIMS, Delhi and obtained MD Degree in Medicine in the year 1988. After post-graduation, he returned to Nepal and worked for a number of years at IOM, Maharajgunj as a Lecturer in Medicine. He then joined Kathmandu Medical College, where he worked as a Senior Consultant Physician from $1^{\text {st }}$ May, 2000 until his last days of life.

Dr. Rana was born in a privileged Rana family. Rudra Shamsher JB Rana, Son of Bir Shamsher JB Rana was his great grandfather. Dr. Biru was the grandson of Raj Shamsher JB Rana and second son of Bhakti Shamsher JB Rana. Dr. Rana did not like the sponsorship of pharmaceutical companies. In Nepal and neighboring countries, doctors are sponsored to attend conferences and entertained in various ways. Dr. Rana had a strong feeling against this and he never attended reception sponsored by the pharmaceutical companies.

Dr. Rana, though he appeared fearful from outside, was a very kind hearted person. I have known him helping poor patients by giving them money to buy medicines. Very few people believe that death would come to them any moment in their life - death surly comes to every one of us. Our desire should be to be happy and make others happier by any means. Doctors can make people happy by relieving their suffering from diseases not only by prescribing painkillers but by being kind and assuring patients with confidence. Dr. Biru had some of the qualities mentioned above. He was familiar with good medical practice and applied it while treating his patients.

Dr. Rana was a very good friend and a reliable colleague of mine. His untimely death has made me and all my faculty members very sad. All the faculty members, departmental secretary, Head of Department of Medicine, Cardiology, Neurology and myself as a chairman of the department of medicine would like to wish that Dr. BBS Rana's soul to rest in peace in heaven.

Dr. Biru will be remembered by his patients, relatives and colleagues for many years to come. He is survived by his wife Asha Rana and two sons. One of his sons, Dr. Vikramaditya SJB Rana, is a medical officer working at the Kathmandu Medical College in the Department of Internal Medicine.

Prof. D.B. Karki

Chairman, Department of Medicine HOD, Department of Cardiology $\mathrm{KMCTH}$, Sinamangal 
